Vasyl Nazarkov ${ }^{1}$

\title{
MODERN INTERNAL POLITICAL REFORMS IN THE ARABIAN STATES: KEY REASONS AND IMPLEMENTATION FACTORS
}

Keywords: internal political reforms, the countries of the Arabian Peninsula, political transformations, the process of globalization, gender policy, educational policy.

ABSTRACT: In this article is determined that the main factor that led to political transformations in the Arabian Peninsula was the process of globalization. Moreover, the impact on the countries of this region was carried out in two vectors - externally and internally. As a result of the active promotion of Western traditions of understanding and functioning of political systems, cardinal reforms and transformations in gender policy, education, socio-economic level, etc. have taken place in the countries of the studied region. The relevance of the study of the proposed topic is due to the fact that the Middle East, including and the Arabian Peninsula become important in Ukraine's international relations. Although, as the practice of post-reform events shows, often these changes are only declarative rather than systemic. This is primarily due to the slow and unstable movement towards the transformation of socio-political institutions, despite the rather strong pressure in this context from leading international organizations and the leadership of key Western political states.

It is proved that reforms in the context of gender policy have become a significant transformation of the political structure of the studied countries. This reform was that women began to occupy an important place in society, having the opportunity to hold public office, thus emphasizing its importance in the formation of political elites. Such transformations have undoubtedly affected not only the changing role of women in the context

1 Postgraduate Student at the Departement of Public Administration, Taras Shevchenko National University of Kyiv, nazvas88@gmail.com. ORCID: 0000-00021273-0807. 
of political life, but also the whole of society as a whole - gender equality and respect for women's rights have become an integral part of the existence of each Arab country. Although it is found that today it is impossible to say that gender policy is implemented in the same way as in some leading Western countries, which is due to the presence of society and governments in a situation of choosing between traditional Islamic values and globalization challenges in this context.

\section{INTRODUCTION}

The relevance of the study of the proposed topic is due to the fact that the Middle East, including and the Arabian Peninsula become important in Ukraine's international relations. After all, the foreign policy activity of our state is quite multi-vector, so in some aspects only certain priorities are formed in relation to this region, especially taking into account all the specifics and peculiarities of its functioning. Therefore, a scientific analysis of modern political processes in the Arabian Peninsula in the context of globalization is appropriate for both diplomacies and for a deeper understanding of socio-political transformations in this region of the world.

Thus, the purpose of this scientific investigation is to determine the causes and main vectors of internal political reforms in the Arabian Peninsula.

\section{MAIN REASONS FOR INTERNAL POLITICAL REFORMS}

We can identify the following three key reasons that led to the implementation of political reforms in Arab countries:

- features of internal and foreign policy vectors;

- the specifics of the functioning of national elites;

- public administration system.

At the same time, one of the key reasons for political reforms is the phenomenon of globalization. This process in controversial because it has 
both positive and negative sides. There are fierce discussions about the environmental, economic and social consequences of globalization. Cultural globalization is no less controversial because it involves ordinary people, not just economists, bureaucrats and politicians. Phenomena of different order make us understand the manifestations of globalization in the media, i.e. to assume that the globalization of social and cultural life becomes possible in the most developed media systems.

Globalization - an objective process, its development and mechanisms are determined by many actors in the world community. In this context, it is of considerable practical interest to define the positions of the Arab world in the rapid process of globalization, actively moving in the XXI century, no matter how remote it may seem at first glance.

The process of globalization, that the Arab world is experiencing, shows that East and West are moving towards each other.

Among the most important indicators of economic globalization for the Arab countries are the following:

- growth of foreign direct investment;

- strengthening cooperation between entrepreneurs, intensification of business relations between Arab and Western partners;

- uneven distribution of world resources (concentration of fuel and energy) (Isaev V. \& Filonik A., 2003, p. 115).

Thus, globalization affects them both internally and externally. In terms of interiors, globalization challenges are driving Arab countries to dynamic processes, which is expressed in the gradual reform of certain political institutions, ie their manifestation in such features as is characteristic of classical Western traditions, but also with the preservation of their own national models of the political system. Accordingly, the modernization of political systems in the Arabian states in such as Western countries, has become both a task and a problem, because it required both real and effective reforms in socio-political life, and taking into account their own worldviews.

Therefore, we can state that the modernization of the political system in the states of the Arabian Peninsula is mostly declarative, situational, rather than systemic and thorough. This is primarily due to the slow and unstable movement towards the transformation of socio-political institu- 
tions, despite the rather strong pressure in this context from leading international organizations and the leadership of key Western political states.

However, there are three trends that have contributed to the reform of political systems based on close cooperation between key Western countries and the Arabian Peninsula.

- First, Western countries are increasingly understanding and seeing their failure to pressure and promote their own models of the political system in the region.

- Second, the Arabian countries themselves have a history of creating and developing modernization processes for their political systems. Although it should be noted that this is happening much more slowly than in the West, there is no reason to state the fact that the reform of political systems in the region can be called as having no prospects, or its anti-democratic vector of functioning.

- Third, although Western models of political systems are considered ideal, they cannot be considered exemplary or the only ones that are right for development and political transformation for the Arab states. After all, there are other models such as the «Eastern type», ie such a vector of a transformation of the political system, which is aimed at combining both the principles of democracy and constitutional norms and separate political culture, which is influenced by religious or regional specifics (Strilchuk L., 2013, p. 118).

Over the decades of global integration processes in the Arab world, huge differences in socio-economic development have not been overcome, and the Arab peoples remain a fragmented nation due to the persistence and, in some cases, even greater differentiation that divides Arab states into diametrically opposed regional niches of political and economic spaces.

Such differentiation is largely due to the fact that the Middle East today is a modern model of world postcolonial construction. During this period, for the first time there was a problem of North-South relations, which in the late XX - early XXI century. acquired a new sound. If at first this problem was interpreted through the prism of providing material assistance to the newly formed independent states, then over time it became 
identical to the contradictions that arose between industrialized and developing countries (Melkumyan E., 2018, p. 115). The latter include the countries of the Middle East.

Also the situation is complicated by the fact that today the Arab world can be divided into rich oil-producing countries, developed in this area and backward. Thus, there was formed its «golden billion», its «rich North» and its "poor South», which in turn gives us the problem of double contradictions, both globally and regionally.

The political component of globalization forms for us particular interest. There is no single view on this issue. Thus, according to M. Kamrava, one of the leading Arab experts on global integration processes, at the moment for the Middle East does not exist from a political point of view such a concept as globalization (Enikeev R., 2017, p. 107). He, like many other researchers on the subject, insists that this term hides the violent Americanization and expansion of democracy.

It should also be emphasized that to promote the process of political integration of the Arab countries, which involves the formation of supranational governments (by analogy with the European Union) is problematic but vital for the region, as one of the fundamental foundations of the emerging architecture of the modern world is gradual progress from national to supranational level of state, socio-political structures (Bogatyiy V., 2005, p. 195).

Despite differences of opinion on the phenomenon of globalization, most Arab scholars and intellectuals are concerned about «the general unpreparedness of most countries in the Arab world to enter on an equal footing into the new system of relations represented by globalization» (Abdulbari K., 2002, p. 13). Of particular concern is the possibility of losing national identity, secular and religious traditions. However, almost all researchers of the phenomenon of globalization in the Arab world emphasize the need to reform the economic and political spheres while preserving the national, ethnic and religious characteristics that currently exist in the Arab world. The need to consolidate the efforts of all states in the region to enter the new system of international relations on an equal footing is noteworthy. 


\section{IMPLEMENTATION FACTORS OF INTERNAL POLICIAL REFORM}

If we talk about the key aspects of political reforms, we can identify the following modernization of political and social structures, reform of the education system, as well as changes in gender policy.

Accordingly, the main catalyst in the modernization of political structures in the study region were liberal movements, which covered virtually all countries of the Arabian Peninsula. It was they who helped to enable the process of implementing liberal values in politics and to convince the political elites of the Arabian states of the importance of these transformations. All liberal movements, in contrast to destructive movements, are distinguished by the fact that in their efforts to modernize the political system they tried not to use destructive or confrontational means to cooperate with the ruling elites of a country.

The emphasis on education reform as an aspect of policy reforms is due to the fact that this area is one of the main ones that formed the basis of change in the Arabian Peninsula.

In general, it should be emphasized that at the beginning of the XXI century. in the context of global transformations taking place in the field of science and technology, the problem of competitiveness of scientific knowledge and education is becoming increasingly important. In today's world, education is often perceived not only as a major social institution, an important element of future development and stability, but also as a socio-cultural value closely linked to the preservation of national identity in globalized multicultural societies. Today, knowledge is more than ever a real political and social force.

And it is no coincidence that experts note the close relationship between the socio-political system, the economy and education. Education is seen as a leading factor in the development of culture and economic growth of the country, as increasing the spiritual and intellectual potential of the people, economic and political stability of the state are directly related to the level of intellectual development, his ability and willingness to acquire professional knowledge. 
Current trends of intensifying globalization processes in the field of secondary and higher education (purposeful Americanization) threaten the preservation of national culture, traditions and education, which are closely related to the problems of preserving national identity. That is why the problem of creating effective primary and secondary education by returning to the national-historical experience of pedagogical activity based on national traditions and priorities comes to the fore in the state security strategy. In the XXI century. The world's political processes will be managed by those countries that today invest the most in the education system and educational technologies (Tsivatyi V., Martyniuk, V. \& Tolkach, V., 2013, p. 86).

This reform is due to the fact that in these countries, educational institutions have ceased to be "closed» only in their region in particular, or in the Arab world in general. Then began a very active interaction with various Western and Eastern research and educational institutions and adding significant investment in strong infrastructure development of Arabian universities and research institutes to compete in the global market of educational and research services, as well as highly qualified graduates for their countries; this is especially true of economic, government and tourism specialties.

Changes in gender policy are also a significant transformation of the political structure of the states in the study region. We can say that over the past 30 years, gender policy has changed significantly in the Arabian Peninsula, which has manifested itself in the ability of women to vote, hold representative and public office, and to promote equal rights with men.

The reform was that women began to be understood and identified no longer as an object but as a subject of political life, noting its growing importance in forming its own political elite. It was important that the Constitutions of the Arab countries enshrined gender equality, respect for women's rights and ensuring their fundamental freedoms in all spheres of socio-political life. Accordingly, it is emphasized that the most effective in this context are the reforms carried out by the Government of the Emirates, which in 2009 adopted at the state level Women's Leadership Program, which provided for the creation of a separate system of various institu- 
tions, centers, educational and cultural institutions. a large number of vacancies for women in the emirates (Melkumyan E., 2018, p. 303).

At present, the full-fledged reform has a future, as its effectiveness in the countries of the study region depends on the ability of the societies of these countries to adapt and transform in this direction in accordance with globalization demands, which often contrast with the established worldview and understanding of Islamic society. concepts such as equality, tolerance, individual freedom and justice. Because of this, the governments and societies of the states under study are still in a situation of dilemma and a balanced choice between traditional notions of the role of women in these societies and their Western, globalized perceptions.

However, it should be noted that such drastic reforms could not but affect the foreign policy of the Arabian Peninsula. Thus, in particular, it can be noted that Bahrain took an active part in the activities of the GCC and other Arab intergovernmental organizations, but there were conflicts with a number of countries in the Arabian Peninsula, namely Qatar and Saudi Arabia. In addition, the country has a fairly close international relationship with Western countries such as Britain and the United States; with the latter, in particular, an agreement was even signed on the location of a military base in Bahrain. However, before the post-bipolar period, Qatar's foreign policy was characterized by active involvement in various political conflicts in the Middle East. However, since 1990 and to this day, its role as a mediator in various contradictions between the countries of the Arabian Peninsula has been largely observed. A special feature of its activities in Qatar is the active involvement of sports diplomacy.

Also, it should be noted that the specifics of the functioning of the foreign policy vector in Oman is that most of the emphasis in it was on the countries of the Arab-Muslim world, in particular the countries of Arabia. However, active cooperation is also carried out with a number of countries in the Far East. The peculiarity of Kuwait's foreign policy is that in addition to the established political and economic aspect, the humanitarian sphere is of great importance. Internationally, the Arabian Peninsula is a leader in humanitarian aid to developing countries or those in difficult political circumstances (Syria). Yemen's foreign policy, in contrast to Kuwait, does not pay enough attention to humanitarian activities, but tries 
to pursue it exclusively in peaceful, constructive forms. This is manifested both in peaceful coexistence with neighboring states on the Arabian Peninsula (Saudi Arabia). In turn, it has been proven that the UAE has declared itself a peaceful country in the context of regional relations from the very beginning, but conflicts with Iran have repeatedly been observed for controversial territory (Tsivatyi V., Martyniuk, V. \& Tolkach, V., 2013, p. 82).

Accordingly, globalization processes, which contributed to the deepening of cooperation between the countries of the study region and key global political organizations in the financial and economic sphere, became the catalyst for the first to adopt and implement reforms to improve legislation and implement in accordance with generally accepted standards. As a result of the events of September 11,2001, cooperation in the military-security context became particularly active. Here it has two vectors: on the one hand, Western countries help with weapons and security, and on the other hand, the Arab countries allow certain countries (USA, UK) to deploy powerful military bases on the peninsula to prevent various terrorist riots and incidents. At the same time, strong cooperation between the Arab states and leading intergovernmental organizations in the humanitarian sphere has begun, especially in helping those countries that suffer from armed (mostly civil) conflicts, as well as due to social problems - unemployment, hunger and others.

\section{CONCLUSIONS}

Thus, analyzing the main causes and aspects of internal political reforms in the country of Arabian Peninsula, we can draw the following conclusions:

1) the main factor that led to political transformation in the Arabian Peninsula was the process of globalization. Moreover, the impact on the countries of this region was carried out in two vectors - externally and internally. As a result of the active promotion of Western traditions of understanding and functioning of political systems, radical reforms, and 
transformations in gender policy, education, socio-economic level, etc. have taken place in the countries of the studied region.

2) internal reforms have contributed to changes in the participation of the Arabian Peninsula in the functioning of regional and international organizations. Thus, the activities (active or passive) of the leadership of the Arabian Peninsula largely depended on various local/global economic or military conflicts.

\section{BIBLIOGRAPHY:}

Abdulbari, K. (2002). Politika Yemena na mezhdunarodnoy arene v 80-90 gg. XX v.: Vnutrennie $i$ vneshnie faktoryi [Politics of Yemen in the international arena in the 80-90s. XX century: Internal and external factors] (PhD-theses), Sankt-Peterburg: Sankt-Peterburg State University Publishing House.

Bogatyiy, V. (2005). Evolyutsiya vneshney politiki stran Persidskogo zaliva v period iranoirakskoy voynyi [Evolution of foreign policy of the Persian Gulf countries during the Iran-Iraq war]. Bulletin of the Odessa National University, vol. 10, no. 11, pp. 194-201.

Enikeev, R. (2017). Vliyanie regionalnyih sil na voenno-politicheskuyu situatsiyu v Yemene [Influence of regional forces on the military-political situation in Yemen]. Problems of national strategy Problemyi natsionalnoy strategii, no. 4(43), pp. 77-93.

Isaev, V. \& Filonik, A. (2003). Kuveyt: konturyi ekonomicheskih peremen (opyit razvitiya $v$ usloviyah perehoda ot izbyitka $k$ otnositelnomu defitsitu kapitalov) [Kuwait: the contours of economic changes (experience of development in the conditions of transition from surplus to relative deficit of capital)]. Moskow: «ASTI-IZDAT». [in Russian]

Melkumyan, E. (2018). Gumanitarnaya deyatelnost arabskih monarhiy Persidskogo zaliva [Humanitarian activity of the Arab monarchies of the Persian Gulf]. Paths to Peace and Security. Special issue: Humanitarian challenges, humanitarian response and protection of civilians in armed conflicts, no. 1 (54), pp. 299-307.

Strilchuk, L. (2013). Evoliutsiia blyzkoskhidnoi polityky SShA shchodo Iraku (90-ti roky XX - poch. XXI st.) [Evolution of the US Middle East policy towards Iraq (90s of the XX - early XXI century)]. Scientific Bulletin of the Lesia Ukrainka East European National University. World History, no. 21, pp. 16-121.

Tsivatyi V., Martyniuk, V. \& Tolkach, V. (2013). Pravliacha dynastiia derzhavy Kuveit u nynishnikh politychnykh realiiakh [The ruling dynasty of the state of Kuwait in the current political realities]. Scientific Bulletin of the Diplomatic Academy of Ukraine. Issue 20. Foreign policy and diplomacy: traditions, trends, experience, vol. 20, pp. 8-89. 